\title{
公共基础课“思政”元素在疫情期间的课程融入
}

\author{
Integration of "Ideological and Political" Element \\ in Public Basic Courses During the Epidemic \\ 李敏
}

Min Li

东营科技职业学院

中国·山东 东营 257335

Dongying Vocational College of Science \& Technology,

Dongying, Shandong, 257335, China
【摘 要】众志成城抗击疫情。基础部全体教师积极响应习近平总书记“把人民群众生命 安全和身体健康放在第一位, 全面打赢新型冠状病毒肺炎阻击战的要求”, 响应学院根据 教育部统一部署的“停课不停学”的号召,在疫情期间利用网课对学生进行抗疫思政教育。

【Abstract】All the teachers in the city are fighting against the epidemic. All teachers in the basic department actively respond to the General Secretary Xi Jinping to put people's lives and health in the first place, and comprehensively win the COVID-19 battle, and the call according to the unified deployment of the Ministry of Education of "non-stop school", and use online courses to educate students on anti-epidemic ideology and politics during the outbreak.

【关键词】公共基础课; 思政;课程教育

【Keywords \public basic courses; ideological and political; curriculum education

【DOI】10.36012/sde.v2i3.1618

\section{1 思政课作为主阵地}

思政教研室首先立即行动, 主要针对《毛泽东思想和中国 特色社会主义理论体系概论》课程, 要求每位任课教师认真备 课, 提前做好一切准备工作。于 2 月 20 日开始启动,按学校安 排课表开始上课。

《毛泽东思想和中国特色社会主义理论体系概论》课程在 优慕课原有资源的基础上，本课程任课教师及时更新一些有 特色、代表性强、数量充足的思政在线教学资源和在线试题, 服务学生在线学习, 提高了学生学习积极性和课程挑战性 ${ }^{[1]}$ 。 针对思政课程特点, 为更好解读以习近平同志为核心的党中 央关于疫情防控的决策部署，分析中国抗疫彰显的中国共产 党领导和中国特色社会主义制度的显著优势, 讲述防疫战疫 一线的感人故事, 发挥高校思政课落实立德树人根本任务的 关键课程作用,新增两个专题:
(1)开学第一课:战“疫”, 我们在一起!

(2)教育部组织的全国大学生同上一堂思政课。

与此同时，思政课增加了相关的疫情知识以及防护的讨 论和作业, 引导学生关注疫情, 了解国家的相关政策, 增强学 生的责任感和爱国感。

\section{2 英语课堂 : 让学生感受特殊时期语言的} 力量

全国上下抗战疫情的特殊时刻，英语教研室积极探索特 殊时期课程思政融入课堂教学的教学模式，特开启了“What President Xi Says (习近平说)”板块, 在每次直播答疑课程前 10 分钟, 为学生选取 “What President Xi Says (总书记说)”中 关于战“疫”的经典言论,进行关键词的讲解,共融入抗疫经典 演讲《We Are All Fighters》, 让学生感受特殊时期语言的力 量, 课堂发起讨论并行成共识: “我们为什么学习外语?我觉得 
学科教育 Subject Education

其中一个重要的原因, 就是为了让世界了解我们,让世界看到 我们中国青年的精神面貌,消除误解和偏见,传递正确的价值 观。”战“疫”课程思政融人大学英语线上教学, 在进行语言学 习的同时,提升学生的民族自豪感和责任意识。

\section{3 大学体育:强身健体,开展生命健康教育}

基础部大学体育以此次疫情防控为契机, 加强生命健康 教育, 积极宣讲新型冠状病毒、新型冠状病毒肺炎疫情及其防 护知识,促使大学生增强自我防护意识,落实自我防护措施。 要引导大学生珍爱生命, 牢固树立预防为主、健康第一的观 念, 在日常生活学习中养成良好的卫生习惯, 自觉加强体育锻 炼, 增强身体素质, 提升自身免疫力; 培养良好的生活习惯、理 性平和的心态、文明健康和绿色环保的生活方式, 有相关症状 及时就诊, 保护身体健康 ${ }^{[2]}$

\section{4 高数课堂: 树立合作精神, 培养家国情怀}

众志成城, 共同抗疫背景下,高等数学积极进行思政内容 融入, 在教学内容上借助数学家的故事、数学史、知识点及数 学方法等适时载入思政元素,将德育与知识教学融于一体, 培 养学生爱国、正直、诚信、创新的品行, 同时助力提高学生的社 会服务能力 ${ }^{[3]}$ 。

德是做人之本, 德育是教育之魂。课程思政指以构建全 员、全程、全课程育人格局的形式将各类课程与思想政治理论 课同向同行,形成协同效应,把“立德树人”作为教育的根本任 务的一种综合教育理念 ${ }^{[4]}$ 。学校基础部数学组全体教师结合 自身的工作经验和对数学学科的深刻认识从 “认识和传播数 学文化” “诱发对数学之美的探索” “阐释数学哲学与人生价 值”等方面讨论如何做到“知识传授与价值引领相结合”的有 效路径, 提炼的数学德育内容为: 培养严谨态度, 崇尚理性精 神,提升数学审美,培养家国情怀[5]。

\section{5 从学生的日常行为进行思政教育}

从学生的日常行为进行思政教育,培养严谨态度, 要求学 生不迟到、不旷课, 提前到课堂, 就是教育学生履行契约 $[6]$ 。要 求学生上课遵守纪律, 认真听课, 就是要求学生尊重他人的付
出,规范学生的学习习惯。

学生抄作业的习惯是日积月累的结果。教师要分析抄的 原因,针对性交流,让其重新写作业。对于不改的,作业成绩零 分记录。教育学生做人做事要有严谨的态度。

职业院校数学教育素质目标: (1)使学生认识到数学来源 于实践又服务于实践, 从而树立辩证唯物主义世界观; (2)培养 学生良好的学习习惯、数学素养和思维严谨、工作求实的作 风; (3)培养学生优良的道德品质、坚强的意志品格, 勇于探索、 敢于创新的思想意识和良好的团队合作精神。我们的数学教 学始终围绕着这个目标进行 ${ }^{[7]}$ 。

\section{6 结语}

“新型冠状病毒肺炎疫情的突袭让 2020 年春天注定成为 中华民族史册上难以忘却的一页。”公共课教师带领同学们深 刻理解抗击新型冠状病毒肺炎疫情的中国实力、中国制度、中 国力量, 同时还聚焦战“疫”事迹育人元素, 从数字抗“疫”、人 物群像、凡人金句、国际评价等方面逐步深人,充分发挥了疫 情期间思政教育的积极性和主动性，充分发挥了中华民族每 一个个体的精神力量和责任担当!

\section{参考文献}

[1]施雯,王克波,曹松玉,等.首届全国大学生公共卫生综合技能大 赛背景下的公共卫生实践课程教学探索[丁.医学教育研究与实践,2020, 28(3):401-404.

[2]㟟翔荣.问题意识培养视域下 “政策调查”教学法的探索与实 践一以以“公共政策分析”课程为例 [J].黑龙江教育(高教研究与评 估),2020(5):9-11.

[3] 供金平. “全媒体时代” 大学公共影视课程的现状与对策探 讨一以复旦大学为例 [J].当代教育理论与实践,2020,12(3):62-67.

[4]公共基础课在高职人才培养中的作用及教学探索——以思政 课为例[J].创新创业理论研究与实践, 2018,1(8):28-29.

[5]思政教育融人高职数学课程的教学改革实践探索 [J].浙江交 通职业技术学院学报,2018(4):64-67.

[6]“大思政”背景下高职院校公共基础课程教学改革与建设研究 [J].中华传奇,2019(10):165-166.

[7]远程教育中《高等数学基础》课程思政,实践探索[J].山西广播 电视大学学报,2019(2):29-32. 